\title{
Effect of organic manures and different levels of NPK on growth and quality of bottle gourd [Lagenaria siceraria (Mol.) Standl.]
}

\author{
M Nagar, AK Soni, DK Sarolia \& HR Saini
}

Journal of Agriculture and Ecology

ISSN: 2456-9410

Volume: 4

Journal of Agriculture and Ecology (2017) 4: 44-50 http://doi.org/10.53911/JAE.2017.4206

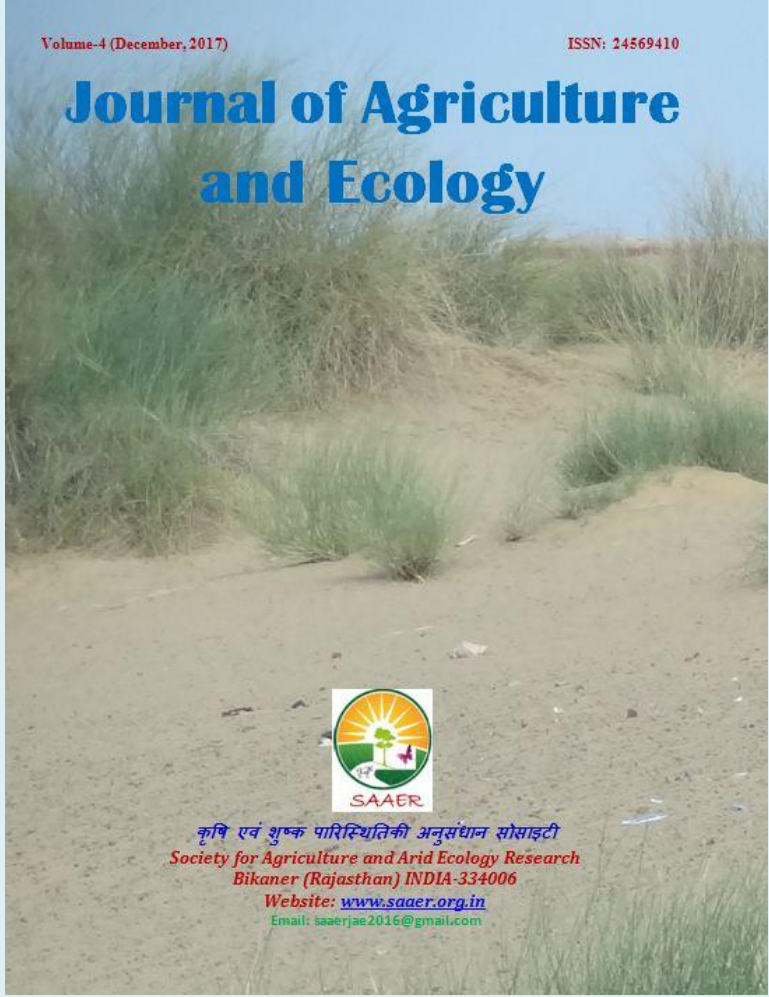




\title{
Effect of organic manures and different levels of NPK on growth and quality of bottle gourd [Lagenaria siceraria (Mol.) Standl.]
}

\author{
M Nagar $¥$, AK Soni, DK Sarolia \& HR Saini \\ Department of Horticulture, College of Agriculture
}

S K Rajasthan Agricultural University, Bikaner 334006, Rajasthan, India

$\square$ Corresponding author: M Nagar, E-mail: $\underline{\text { mkdhakar9680@gmail.com }}$

\section{Article Info}

Article history

Received: 15 September, 2017

Accepted: 28 October, 2017

Available online: 30

November 2017

Key Words: Bottle gourd, poultry manure, vermincompost

Abstract

A field experiment was conducted during kharif, season 2012 to study the effect of organic manures and different levels of NPK on growth and quality of Bottle gourd. The experiment consisting of 16 treatments viz., four levels of NPK (control, 100:50:50, 80:40:40 and 60:30:30) and organic manures (control, vermicompost, poultry manure and FYM) designed in factorial RBD with three replications. Results indicated that application of NPK (100:50:50) + vermicompost $(5.0 \mathrm{t} / \mathrm{ha})$ was recorded minimum days taken to appearance of first female flower, maximum length of main vine (m), number of primary branches per vine, length and width of leaf (cm) 45 days after sowing, minimum node number at first female flower appeared, protein content in fruit, crude fibre content in fruit, nitrogen content in fruit, phosphorus content in fruit, potassium content in fruit, yield $\mathrm{q} / \mathrm{ha}$ and return rupees investment.

Copyright (C2017 Nagar et al.., This is an open access article published under the terms of the Creative Commons Attribution License, which permits unrestricted use, distribution, and reproduction in any medium, provided the original work is properly cited.

Preferred citation: Nagar M, Soni AK, Sarolia DK \& Saini HR. 2017. Effect of organic manures and different levels of NPK on growth and quality of bottle gourd [Lagenaria siceraria (Mol.) Standl.]. Journal of Agriculture and Ecology, 4: 44-50; http://doi.org/10.53911/JAE.2017.4206.

\section{Introduction}

Among, cucurbits, bottle gourd [Lagenaria siceraria (Mol.) Standl.] is extensively grown in India and fruits are available throughout the year. Fruits at tender stage are used as a cooked vegetable and for preparation of sweets (e.g. kheer, petha, burfi, and halwa) and pickles, rayta. Hard shells of mature fruits are used as water jugs, domestic utensils, floats for fishing nets and making musical instruments, etc. As a vegetable it is easily digestible. It has cooling effect and has diuretic and having cardio-tonic properties. Fruit pulp is used as an antidote against certain poisons and is good for controlling constipation, night blindness and cough. A decoction made out of leaf is taken for curing 
jaundice (Thamburaj \& Singh 2001). The fruit contain $0.2 \%$ protein, $2.9 \%$ carbohydrate, $0.5 \%$ fat and $11 \mathrm{mg}$ vitamin $\mathrm{C}$ of per $100 \mathrm{~g}$ fresh weight. In the area, cucurbits are growing extensively as kitchen garden especially during kharif season or as commercial scale throughout the year. The tribal's of the area are growing it and train the vines on boundary of the house and on pandal. Among cucurbits, bottle gourd is being grown by majority of the farmer than other cucurbitaceous vegetables In India, bottle gourd is grown in the area of 111 thousand hectares with annual production of 1836 thousand tonne and having 12.21 tonnes $\mathrm{ha}^{-1}$ productivity. It occupies 3.20 Thousand hectares area in Rajasthan producing 22.40 tonne with a productivity of 3.48 tonnes $\mathrm{ha}^{-1}$ (Anonymous 2015). The effect of organic and inorganic fertilizers is complementary to each other in terms of soil fertility improvement and sustainable agriculture. Therefore, it is necessary to make their judicious use in right proportion for harvesting better yield of different crops in cropping sequence and for sustaining soil fertility. The integrated nutrient management helps in restoring and sustaining soil fertility and crop productivity. It also helps in arresting the emerging deficiencies of macro, secondary and micronutrients favorably by optimizing the physical, chemical and biological environment of soil and achieving economy and efficiency in fertilizer use. Hence, the present study was undertaken to find out the combined effect of organic manures and inorganic fertilizers on the growth and quality of bottle gourd.

\section{Materials and Methods}

The experiment was laid out at Horticulture Farm, College of Agriculture, Bikaner, during Kharif season 2012. The soil was loamy sandy with $\mathrm{p}^{\mathrm{H}} 8.2$ and contained $0.09 \%$ organic carbon, $80.19 \mathrm{~kg} \mathrm{ha}^{-1}$ available $\mathrm{N}, 17.34 \mathrm{~kg} \mathrm{ha}^{-1}$ available $\mathrm{P}, 185.42 \mathrm{~kg} \mathrm{ha}^{-}$ ${ }^{1}$ available $\mathrm{K}$. The experiment was laid out in Randomized Block Design (factorial) with three replications. There were sixteen treatment combinations, which included various combination of NPK (control, 100:50:50, 80:40:40 and 60:30:30) and organic manures (control, vermicompost, poultry manure and FYM). The well rotten farm yard manure $\left(5.0 \mathrm{t} \mathrm{ha}^{-1}\right)$, vermicompost $\left(5.0 \mathrm{t} \mathrm{ha}^{-1}\right)$ and poultry manure $\left(7.0 \mathrm{t} \mathrm{ha}^{-1}\right)$ were applied and spread uniformly in the plots as per treatment. Three seeds per hill were sown manually by dibbling method on $3^{\text {rd }}$ August 2012. The seeds were soaked in cold water overnight before sowing for better germination. The sowing was done in the row keeping $2.5 \mathrm{~m}$ inter -row spacing and $0.80 \mathrm{~m}$ plant to plant spacing. At each hill and seed were sown at a depth of 1.5 to $2.0 \mathrm{~cm}$. Germination took place within six days after sowing. One third dose of $\mathrm{N}$, full doses of phosphorus and potassium were applied at the time of sowing. The remaining doses of nitrogen were applied 30 and 60 days after sowing into standing crop. The sources of $\mathrm{N}$, $\mathrm{P}$ and $\mathrm{K}$ were used as urea, single super phosphate and muriate of potash, respectively ansd the recommended dose of NPK was 80:40:40 kg ha ${ }^{-1}$ (Anonymous 2010). Five plants were selected randomly from each plot and tagged for data recording. Minimum days taken to appearance of first female flower, length of main vine $(\mathrm{m})$, number of primary 
branches per vine, length and width of leaf (cm) 45 days after sowing, minimum node number at first female flower appeared, protein, crude fibre, nitrogen, phosphorus, potassium content in fruit, yield $\mathrm{q} / \mathrm{ha}$ and return rupees investment were recorded as per standard methodology. Estimated yield per hectare was calculated by number of fruit vine $^{-1}$, yield vine ${ }^{-1}$ and total plant density and returns ha ${ }^{-1}$ calculated by sale price of Rs 800 $\mathrm{q}$ and total yield $\mathrm{q} \mathrm{ha}{ }^{-1}$. Where returns rupees investment calculated by dividing net return to total cost of cultivation ha ${ }^{-1}$.

\section{Results and Discussion}

Effect of organic manure: The data presented in (Table 1 and Table 2). Organic manures, NPK levels effect on growth and quality attributes of bottle gourd. The application of vermicompost (5.0 $\left.\mathrm{t} \mathrm{ha} \mathrm{ha}^{-1}\right)$. Recorded length of main vine (4.09), number of primary branches per vine (11.85), protein content in fruit $(0.262 \%)$, crude fibre content in fruit $(1.136 \%)$, nitrogen content in fruit $(0.042 \%)$, phosphorus content in fruit $(0.41$ $\%)$, and yield $\mathrm{q} /$ ha $\left(242.70 \mathrm{q}^{\text {ha-1 }}\right)$. However application of FYM (5.0 $\left.\mathrm{t} \mathrm{ha}^{-1}\right)$, recorded minimum node number at first female flower appeared (11.64), length of leaf $(18.16 \mathrm{~cm})$ and width of leaf $(27.21 \mathrm{~cm}), 45$ days after sowing, potassium content in fruit $(1.52 \%)$, and minimum days taken to appearance of first female flower (58.47), under poultry manure $\left(7.0 \mathrm{t} \mathrm{ha}^{-1}\right)$. These finding clearly indicated that vermicompost played a significant role on enhancing the growth of bottle gourd. Improvement in plant growth attributes with that application of vermicompost might be due to better not only provided plant nutrient but also improve the physical condition of soil in respect of granulation, friability porosity which interm provided a balance nutritional environment favorable both soil rhizosphere and in plant system. Reddy et al. (1998). These results are in close conformity with the finding of Senapati et al. (1985), Pillai et al. (1985), Sharhidhara et al. (1998) and Tomar et al. (1998). This might be due to improved nutrient environment in the rhizosphere as well as its utilization in the plant system, leading enhanced translocation of nutrient, vitamins and proteins in fruits. Another reason might be the increased activity of nitrate reductase which helped in synthesis sustains amino acid proteins as reported by Chinaswamy \& Marikulandi (1966); Lopes et al. (1996); Yadav \& Vijayakumari (2004); Meena et al. 2016. The beneficial effect of FYM/ Vermicompost in increasing the content of nitrogen in fruit might be attributed to its direct supply of nitrogen. Moreover, FYM/ Vermicompost after decomposition might have released macro and micro-nutrients, which increases the availability of nutrients to the soil, plant system and thus increased the nutrient in fruit etc. The higher nutrient availability enhanced photosynthesis and their translocation to different plant parts resulting into higher concentration of nutrient particularly, nitrogen. Similar finding have been observed by Singh \& Krishana (2007), Ouda \& Mahadeen (2008), Balai et al. (2017).

Effect of inorganic fertilizers: Application of different levels NPK significantly influenced the growth and yield of bottle gourd. The maximum number of primary branches per vine (12.55), length of leaf $(18.65 \mathrm{~cm})$, width of leaf $(27.54 \mathrm{~cm}) 45$ days 
after sowing, minimum node number at first female flower appeared (11.27), protein content in fruit $(0.81 \%)$, crude fibre content in fruit $(0.139 \%)$, nitrogen content in fruit $(0.045 \%)$, phosphorus content in fruit $(0.45$ $\%)$, potassium content in fruit $(1.74 \%)$ and yield (249.10 q/ha) were recorded under NPK 100:50:50 fertilizer. However the NPK levels 80:40:40 fertilizers recorded maximum length of main vine $(4.27 \mathrm{~m})$, minimum days taken to appearance of first female flower (58.22). This may be due to the better nutrition environment in the root zone for growth and development of the plant. Nitrogen is considered as one of the major nutrient required for proper growth and development of the plants. It also play an important role in plant metabolism by virtue of being an essential constituent of diverse type of metabolically active compounds like amino acids, proteins, nucleic acids, prophytins, flavins, purine and pyrimidine, nucleotide, flavin nucleotides, enzymes, coenzymes and alkaloid (Yadav 2000). Phosphorus is a constituent of nucleic acid, phytin and phospholipids. The beneficial influence of phosphorus in early stages of growth may be explained by early stimulation of root system through efficient translocation to the root of certain growth stimulation compounds formed on account of protoplasmic activity of tops in phosphorus feed plants, when enhanced absorption of nitrogen and other nutrient and their utilization. So an adequate supply of phosphorus in early stages of plant life is important in laying down the primodia for the reproductive part of the cauliflower Kumar et al. (2004). The response of potassium fertilization in terms of overall improvement in growth characters is further supported by the fact that the leaching losses of potassium were more in light textured soil. Therefore, potassium fertilization improved overall crop growth in term of plant minimum day taken to the appearance of first female flower, minimum nodes no. at which first female flower appeared, length of main vine, number of primary branches per plant, length and width of leaf $(\mathrm{cm}) 45$ day after sowing, potassium helps in the protein and chlorophyll formation ultimately the NPK are used for better vegetative growth. As far case economic is calculated the combined application of $\left(\mathrm{V}_{1} \mathrm{~F}_{3}\right)$ recorded maximum results revealed that organic manure in form of vermicompost @ 5 tonnes ha ${ }^{-1}$ recorded higher growth and yield attributes as well as gross return over rest of treatment. Further in NPK levels higher dose i.e 100:50:50 kg ha-1 respectively showed better in growth and quality tones. The result of present study in the agreement his the earlier researches and returns per rupees investment The influence of nitrogen fertilization of $\mathrm{N}, \mathrm{P}$ and $\mathrm{K}$ content of fruit appeared to be due to improvement nutritional environment both in the root zone in the plant system. Thus, adequate supply of NPK early in the crop season increased the availability of nutrient to the root zone coupled with increased metabolic activity and at the cellular level probably might have increased the nutrient uptake and accumulation in the vegetative plant parts, and fruit highly nutrient contents in fruit seems to be due to higher functional activity of root for longer duration under this treatment the increased NPK in bulb also observed by Hilli et al. (2009). 
Table1. Effect of organic manures and different levels of NPK on growth and quality of Bottle gourd

\begin{tabular}{|c|c|c|c|c|c|c|c|c|c|c|c|c|}
\hline Treatment & $\begin{array}{l}\text { Days } \\
\text { taken } \\
\text { to } \\
\text { appear } \\
\text { ance of } \\
\text { first } \\
\text { female } \\
\text { flower }\end{array}$ & $\begin{array}{l}\text { Leng } \\
\text { th of } \\
\text { main } \\
\text { vine } \\
\text { (m) }\end{array}$ & $\begin{array}{l}\text { No. } \\
\text { of } \\
\text { prima } \\
\text { ry } \\
\text { branc } \\
\text { hes } \\
\text { per } \\
\text { vine }\end{array}$ & $\begin{array}{l}\text { Lengt } \\
\mathrm{h} \text { of } \\
\text { leaf } \\
(\mathrm{cm}) \\
45 \\
\text { days } \\
\text { after } \\
\text { sowin } \\
\mathrm{g}\end{array}$ & $\begin{array}{l}\text { Width } \\
\text { of } \\
\text { leaf } \\
(\mathrm{cm}) \\
45 \\
\text { days } \\
\text { after } \\
\text { sowin } \\
\mathrm{g}\end{array}$ & $\begin{array}{l}\text { Node } \\
\text { no. at } \\
\text { first } \\
\text { femal } \\
\text { e } \\
\text { flowe } \\
\text { r } \\
\text { appea } \\
\text { red }\end{array}$ & $\begin{array}{l}\text { Protei } \\
\mathrm{n} \\
\text { conte } \\
\mathrm{nt} \text { in } \\
\text { fruit } \\
(\%)\end{array}$ & $\begin{array}{l}\text { Crude } \\
\text { fibre } \\
\text { conte } \\
\text { nt in } \\
\text { fruit } \\
(\%)\end{array}$ & $\begin{array}{l}\text { Nitrog } \\
\text { en } \\
\text { content } \\
\text { in fruit } \\
(\%)\end{array}$ & $\begin{array}{l}\text { Phosph } \\
\text { orus } \\
\text { content } \\
\text { in fruit } \\
(\%)\end{array}$ & $\begin{array}{l}\text { Pota } \\
\text { ssiu } \\
\mathrm{m} \\
\text { cont } \\
\text { ent } \\
\text { in } \\
\text { fruit } \\
(\%)\end{array}$ & $\begin{array}{l}\text { Yield } \\
\text { (q/ha) }\end{array}$ \\
\hline Control & 60.85 & 3.66 & 11.38 & 17.41 & 26.60 & 12.35 & 0.225 & 1.124 & 0.036 & 0.36 & 1.20 & 188.22 \\
\hline Vermicompost & 59.25 & 4.09 & 11.85 & 18.09 & 27.03 & 11.65 & 0.262 & 1.136 & 0.042 & 0.41 & 1.50 & 242.70 \\
\hline Poultry manure & 58.47 & 3.85 & 11.61 & 17.87 & 26.98 & 12.03 & 0.256 & 1.127 & 0.041 & 0.34 & 1.45 & 225.17 \\
\hline FYM & 59.62 & 4.05 & 11.58 & 18.16 & 27.21 & 11.64 & 0.256 & 1.131 & 0.041 & 0.38 & 1.52 & 223.26 \\
\hline S.Em \pm & 0.58 & 0.15 & 0.13 & 0.23 & 0.29 & 0.23 & 0.007 & 0.003 & 0.001 & 0.01 & 0.11 & 0.27 \\
\hline C.D. $(P=0.05)$ & 1.68 & NS & NS & NS & NS & NS & NS & NS & NS & 0.03 & NS & 0.78 \\
\hline Control & 60.86 & 3.33 & 9.92 & 16.76 & 25.99 & 12.78 & 0.218 & 1.113 & 0.035 & 0.33 & 1.08 & 176.08 \\
\hline NPK(60:30:30) & 59.97 & 3.79 & 11.74 & 17.57 & 26.84 & 12.28 & 0.243 & 1.131 & 0.039 & 0.40 & 1.19 & 211.96 \\
\hline NPK(80:40:40) & 58.22 & 4.27 & 12.21 & 18.56 & 27.46 & 11.35 & 0.275 & 1.135 & 0.044 & 0.31 & 1.67 & 242.20 \\
\hline NPK(100:50:50) & 58.81 & 4.25 & 12.55 & 18.65 & 27.54 & 11.27 & 0.281 & 0.139 & 0.045 & 0.45 & 1.74 & 249.10 \\
\hline S.Em \pm & 0.58 & 0.15 & 0.13 & 0.23 & 0.29 & 0.23 & 0.007 & 0.003 & 0.001 & 0.01 & 0.11 & 0.27 \\
\hline C.D. $(P=0.05)$ & 1.61 & 0.45 & 0.38 & 0.68 & 0.83 & 0.68 & 0.021 & 0.009 & 0.003 & 0.03 & 0.33 & 0.78 \\
\hline
\end{tabular}

Table 2. The cultivation cost of Bottle gourd including cost of individual treatment ( $₹$ ha $^{-1}$ )

\begin{tabular}{llllclll}
\hline Treatment & $\begin{array}{l}\text { Fruit } \\
\text { Yield } \\
\left(\mathrm{qha}^{-1}\right)\end{array}$ & $\begin{array}{l}\text { Common } \\
\text { cost of } \\
\text { cultivation } \\
\left(₹ \mathrm{ha}^{-1}\right)\end{array}$ & $\begin{array}{l}\text { Treatment } \\
\text { cost } \\
\left(₹ \mathrm{ha}^{-1}\right)\end{array}$ & $\begin{array}{l}\text { Total cost } \\
\left(₹ \mathrm{ha}^{-1}\right)\end{array}$ & $\begin{array}{l}\text { Gross } \\
\text { returns } \\
\left(₹ \mathrm{ha}^{-1}\right)\end{array}$ & $\begin{array}{l}\text { Net returns } \\
\left(₹ \mathrm{ha}^{-1}\right)\end{array}$ & $\begin{array}{l}\text { B:C } \\
\text { ratio }\end{array}$ \\
\hline $\mathrm{V}_{0} \mathrm{~F}_{0}$ & 134.93 & 49245 & 0 & 49245 & 107944 & 58699 & 2.19 \\
$\mathrm{~V}_{2} \mathrm{~F}_{0}$ & 182.96 & 49245 & 10500 & 59745 & 146368 & 86623 & 2.44 \\
$\mathrm{~V}_{0} \mathrm{~F}_{1}$ & 192.56 & 49245 & 2464.53 & 51709.53 & 154048 & 102338.47 & 2.97 \\
$\mathrm{~V}_{0} \mathrm{~F}_{3}$ & 231.56 & 49245 & 4107.58 & 53352.58 & 185248 & 131895.42 & 3.47 \\
$\mathrm{~V}_{1} \mathrm{~F}_{2}$ & 265.98 & 49245 & 18286.02 & 67531.02 & 212784 & 145252.98 & 3.15
\end{tabular}




\begin{tabular}{lccccccc}
$\mathrm{V}_{2} \mathrm{~F}_{1}$ & 215.77 & 49245 & 12964.53 & 62209.53 & 172616 & 110406.47 & 2.77 \\
$\mathrm{~V}_{2} \mathrm{~F}_{3}$ & 231.36 & 49245 & 14607.58 & 63852.58 & 185080 & 121227.42 & 2.89 \\
$\mathrm{~V}_{3} \mathrm{~F}_{2}$ & 238.44 & 49245 & 5786.02 & 55031.02 & 190752 & 135720.98 & 3.46 \\
$\mathrm{~V}_{1} \mathrm{~F}_{0}$ & 195.11 & 49245 & 15000 & 64245 & 156088 & 91843 & 2.42 \\
$\mathrm{~V}_{3} \mathrm{~F}_{0}$ & 191.32 & 49245 & 2500 & 51745 & 153056 & 101311 & 2.95 \\
$\mathrm{~V}_{0} \mathrm{~F}_{2}$ & 193.83 & 49245 & 3286.02 & 525331.02 & 155064 & 10253.98 & 2.99 \\
$\mathrm{~V}_{1} \mathrm{~F}_{1}$ & 211.33 & 49245 & 17464.53 & 66709.53 & 169064 & 102354.47 & 2.53 \\
$\mathrm{~V}_{1} \mathrm{~F}_{3}$ & 298.39 & 49245 & 19107.58 & 68352.58 & 238712 & 170359.42 & 3.49 \\
$\mathrm{~V}_{2} \mathrm{~F}_{2}$ & 270.57 & 49245 & 13786.02 & 63031.02 & 216456 & 153424.98 & 3.43 \\
$\mathrm{~V}_{3} \mathrm{~F}_{1}$ & 228.19 & 49245 & 4964.53 & 54209.53 & 182552 & 128342.47 & 3.36 \\
$\mathrm{~V}_{3} \mathrm{~F}_{3}$ & 235.09 & 49245 & 6607.58 & 55852.58 & 188072 & 132919.42 & 3.36 \\
\hline \multicolumn{5}{l}{ Sale price of bottle gourd @ ₹ $800.0 / \mathrm{q}$} & life of tomato. South & Indian \\
\end{tabular}

On the basis of the results obtained in present investigation, it may be concluded that the application of NPK either alone or in combination with organic manures enhanced the growth and yield attributes in bottle gourd. Supplementation of 5.0 tonnes vermicompost combination with NPK (100:50:50 kg ha ${ }^{-1}$ ) enhanced growth and quality as well as returns

\section{Reference}

Anonymous. 2015. Horticulture Statistics Division, DAC and FW. $07 \mathrm{Ch}$ 07.Indd 194

Anonymous. 2010. Package and Practices of Horticultural crops in Rajasthan. Directorate of Horticulture, Pant Krishi Bhavan, Government of Rajasthan, Jaipur

Chinaswamy KN \& Mariakulandi A. 1966. Influence of organic and inorganic manure on the firmness and storage
Hilli JS, Vyakarnahal BS, Birandar DP \& Ravi H. 2009. Influence of method of trailing and fertilizer levels on seed yield of ridge gourd (Luffa acutangula L. Roxb). Karnataka Journal of Agriculture Science, 22 (1): 47-52.

Kumar SCP, Krishnappa KS, Reddy NS \& Anjanappa M. 2004. Effect of varying levels of NPK on growth and yield of ridge gourd in souther dry region of Karnataka. Mysore Journal of Agriculture Sciences, 38: 4, 446-453.

Lopes AJ, Stamford NP, Eiguerired MVB, Burity NA \& Ferroz EB. 1996. Effect of vermicompost, mineral nitrogen and mineralizing agent on nitrogen fixation and yield in cowpea. Revista Brasileria-de-ciencia-do-Solo, 20: 5562. 
Ouda BA \& Mahadeen AY. 2008. Effect of fertilizers on growth, yield, yield components, quality and certain nutrient contents in broccoli (Brassica oleracea.). Internation Journal of Agricultire Biology, 10: 627-132 .

Pillai KG, Devi SI \& Setty TKP. 1985. Research Achievements of All India Coordinated Agronomical Research Project. Fertilizer News, 30: 26-34.

Reddy R, Reddy M, Reddy TYN, Reddy NS \& Anjnappa M. 1998. Effect of organic and inorganic sources of NPK on growth and yield of pea (Pisum sativum). Legume Research, 21 (1): 57-60.

Senapati BK, Pani SC \& Kabi A. 1985. Effect of earthworm and green manuring on paddy production in pot culture. In. National Seminar on Current trends in soil biology, HAU, India, 71-75.

Sharhidhara GB, Baravaraja PK, Basarajapa R, Jayadesh RC \& Nandagonds VB. 1998. Effect of organic and inorganic fertilizer on growth, yield of byadagi chilli in water and nutrient management for sustainable production and quality of spicea: Proceeding of the National Seminar Medikar, Karnataka, 59-61.

Singh KP \& Mohan K. 2007. intergrated nutrient management for sustainable production of pointed gourd (Trichosanthes dioica Roxb.) under Ganga diara of Bihar. Asian Journal of Horticulture 2 (1): 99-101.
Thamburaj S \& Singh N. 2001. Textbook of vegetables, Tuber crops and Spices Published by Directorate of Information and Publication of Agriculture ICAR, New Delhi pp 2948.

Tomar VK, Bhatnagar RK \& Patta RH. 1998. Effect of vermicompost on production of brinjal and carrot. Bhartiya Krishi Anusandhan Patrika, 13: 153-156,

Yadav RH \& Vijayakumari B. 2004. Impact of vermicompost on biochemical characters of chilli (Capsicum annum). Journal of Ecotoxicology and Environmental Monitoring, 14: 51-56.

Yadav RL. 2000. Response of onion (Allium cepa L.) cultivars to nitrogen and potassium fertilizer under semi-arid conditions of Rajasthan. Ph. D. Thesis, submitted to Raj. Agri. Univ., Bikaner.

Meena NK \& Bhati A. 2016. Response of nitrogen, phosphorous and potassium levels on growth and yield of okra [Abelmoschus esculentus (L.) Moench.]. Journal of Agriculture and Ecology, 2: 1724.

Balai RC, Meena LR \& Sharma SC. 2017. Effect of different levels of nitrogen and phosphorus on cowpea [Vigna unguiculata (L.) Walp] under rainfed conditions of Rajasthan. Journal of Agriculture and Ecology, 3:19-24. 